\title{
亚热带常绿阔叶林不同林层物种多样性与地上生物量的 多变量关系
}

林敦梅 $^{1^{*}}$, 庞梅 ${ }^{1}$, 赖江山 ${ }^{2}$, 米湘成 ${ }^{2}$, 任海保 $^{2}$, 马克平 ${ }^{2}$

1. 重庆大学三峡库区生态环境教育部重点实验室, 重庆 400045;

2. 中国科学院植物研究所植被与环境变化国家重点实验室, 北京 100093

* 联系人, E-mail: lindunmei@cqu.edu.cn

2016-09-26 收稿, 2017-01-05 修回, 2017-01-09 接受, 2017-04-19 网络版发表

国家自然科学基金(31270496, 31500356)和重庆市基础科学与前沿技术研究专项(cstc2016jcyjA0004)资助

摘要物种多样性和生产力(或生物量)间的关系是生态学最关注的问题之一。传统的观点认为群落生产力影响 物种多样性, 而近些年研究发现, 随着物种多样性变化, 群落生产力会发生改变. 不同角度的研究引出了多样性 和生产力之间谁驱动谁的争议. 多变量生产力-多样性假说整合已有观点为解释两者关系提供了一个框架模型, 该假说认为环境除了直接影响生产力外, 还通过影响物种多样性从而间接影响生产力, 而物种多样性则直接决定 群落将环境资源转化为生产力的效率. 本研究利用古田山样地数据对该假说进行了检验. 结果表明, 环境因子直 接影响地上生物量, 并通过影响林冠层优势度和林下层物种丰富度间接影响地上生物量. 优势度对林冠层和林下 层生物量均有直接影响, 但仅有林下层地上生物量受物种丰富度的影响, 这可能与林冠和林下的光照差异引起不 同林层内物种间关系不同有关. 本研究为多变量生产力-多样性假说提供了一个实例, 也表明保护优势物种和维 持高的物种丰富度对森林生物量的提高都是必要的.

关键词生物多样性与生产力，生物量，林冠-林下交互作用，竞争排斥，结构方程模型

生物多样性的维持机制和生物多样性与生态系 统功能关系是近几十年生态学关注的两大核心问题. 对群落物种多样性和生产力(或生物量)进行双变量 分析是研究这两个问题最常见的方式, 但群落生态 学分析的角度是群落生产力如何影响群落物种多样 性的变化 ${ }^{[1,2]}$, 而生态系统生态学分析的角度是群落 的生产力如何响应群落物种多样性的变化 ${ }^{[3]}$. 针对相 同的变量，不同角度的分析引出了一个尚存争议的 问题: 在植物群落中, 是生产力驱动物种多样性的变 化还是物种多样性影响生产力的大小 ${ }^{[4 \sim 7]}$ ? 而且两个 视角研究的结论均还存在争议: 生产力对多样性的 影响研究发现有正影响、负影响及单峰曲线关系 ${ }^{[8]}$,
是否存在普遍规律还有争议 ${ }^{[1,2]}$; 而多样性对生产力 的影响在控制实验中结论较为明确 ${ }^{[9]}$, 但控制实验的 结论很难直接推到复杂的自然群落中 ${ }^{[10]}$.

近些年, 生态学家试图将两个视角的研究结论 整合到一个理论框架下来解释生产力和多样性间的 相互驱动关系. Loreau等人 ${ }^{[6]}$ 和Schmid ${ }^{[7]}$ 分别在他们 的综述和观点论文中提出群落所处的环境决定了群 落中可共存的物种数量, 而群落中的物种数量将决 定群落将环境资源转化成生产力或生物量的能力. 基于此观点, Gross和Cardinale ${ }^{[4]}$ 结合集合群落(metacommunity)和物种竞争共存理论, 通过构建数学模 型验证了此观点的合理性, 提出了“多变量生产力-多 
样性假说”(multivariate productivity-diversity hypothesis $)^{[5]}$. 该假说认为, 群落所处的环境直接影响群落 的生产力; 群落物种多样性直接影响该群落将环境 资源转化为生产力或生物量的能力; 环境通过影响 群落的物种多样性从而间接影响群落的生产力 (图 $1(\mathrm{a}))^{[5]}$. 当环境条件非常苛刻, 仅有适应力强的物种 能在群落中存活, 或环境条件非常优越引起物种间 竞争排斥, 从而仅有竞争能力强的物种能够在群落 中存活, 这两种情况下群落的生产力或生物量大小 主要取决于群落中的优势物种; 而当环境条件适中 从而允许大量物种共存时, 物种间的互补效应将提 高环境资源的利用率, 从而提高群落的生产力(图 1(b)). 目前, 多变量生产力-多样性假说在藻类群 落 $^{[5,11]}$ 和昆虫群落 ${ }^{[12]}$ 的研究中得到实验数据的支持. 近期的整合分析使用森林、草地、海洋浮游生物和滨 海生态系统的数据, 结果总体上符合该假说的预测, 但该分析中森林生态系统的样点仅有一个 ${ }^{[13]}$.

相比于其他植被类型, 森林有着更复杂的垂直 结构. 在天然森林群落中通常少数几个林冠层树种 贡献了群落大部分的生产力或生物量, 林下层物种 对群落的生产力或生物量贡献较小, 但林下层往往 拥有更丰富的物种, 这些物种对塑造林下环境有重 要的作用, 影响着森林的动态、土壤碳库及营养循 环 ${ }^{[14]}$. 然而, 林下层物种在多样性和生产力关系的 研究中常被忽略 ${ }^{[15]}$, 很多研究仅关注群落中胸径较 大的个体 (如胸径 $>5$ 或 $10 \mathrm{~cm})^{[16,17]}$. 由于林下层生物 量小但物种数量却很多, 如果简单地将林下和林冠 的物种多样性和生物量数据分别相加后再进行分析,
由于生物量的增量很小但多样性的增量很大, 分析 结果将可能削弱多样性的重要性. 因此, 将林冠层和 林下层分开进行分析是更为合理的途径.

本研究以中亚热带常绿阔叶林为对象检验多变 量生产力-多样性关系假说的合理性. 鉴于森林垂直 结构的特殊性, 对原有的假说框架进行了改进(图 1(c)), 将物种分成林冠层和林下层两个功能群. 已有 的研究表明，在局域尺度上老龄林的生物量和生产 力之间为正相关关系 ${ }^{[18]}$, 因此本研究使用生物量来 代表生产力. 据预测, 环境因子直接影响林冠层和林 下层的地上生物量, 并通过影响各层的物种多样性 从而间接影响地上生物量; 各林层的物种多样性直 接影响地上生物量的大小, 但不同林层物种多样性 对地上生物量的影响机制存在差异：由于林冠层的 资源非常充足(特别是光照资源), 物种间的竞争排斥 将减少林冠层物种的数量, 竞争能力强的物种对林 冠层的地上生物量起决定性的影响, 而林下层由于 资源受限(特别是光照资源受到林冠层的限制), 物种 间的竞争排斥减小，物种丰富度对地上生物量的影 响增大; 林冠层对林下层有资源竞争, 因此林冠层的 生物量对林下层的生物量和生物多样性产生负的 影响.

\section{1 材料与方法}

( i ) 研究区及样地概况. 本研究地点位于浙江 省开化县苏庄镇境内的古田山国家级自然保护区内 $\left(29^{\circ} 15^{\prime} \mathrm{N}, 118^{\circ} 07^{\prime} \mathrm{E}\right)$. 该保护区于 2001 年成为国家级 自然保护区, 面积约为 $8000 \mathrm{hm}^{2}$. 该地区地处亚热湿 (a)

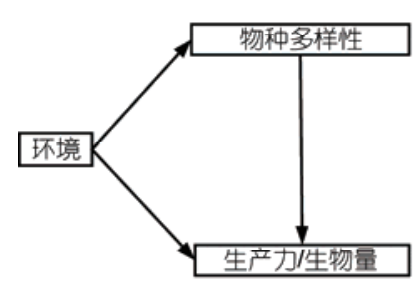

(b)

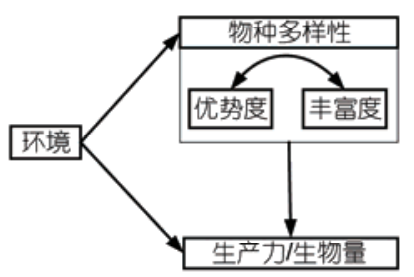

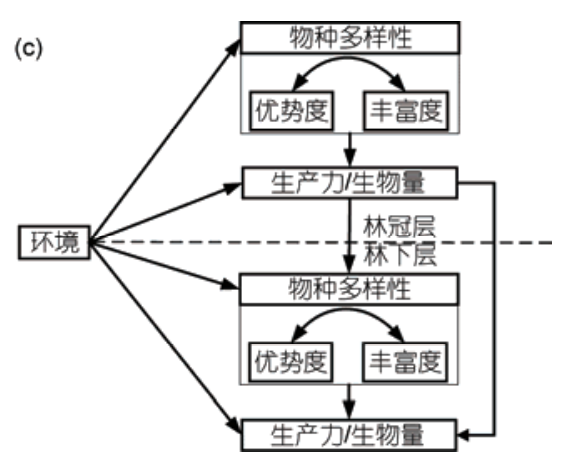

图 1 环境、物种多样性和群落生产力 (或生物量)间的多变量驱动关系概念图. (a) 多变量生产力-多样性假说概念模型 ${ }^{[5]}$; (b) 物种多样性通过 两种互不排次的机制(互补效应和选择效应)影响生产力或生物量; (c) 根据森林垂直结构的特殊性对多变量生产力-多样性说进行的改进

Figure 1 Conceptual diagram illustrating causal relationships between resource availability, biodiversity, and community productivity or biomass. (a) Conceptual framework of multivariate productivity-diversity hypothesis ${ }^{[5]}$; (b) species diversity influences productivity or bimass via two non-mutually exclusive mechanisms: selection effect and complementary effect; (c) multivariate productivity-diversity hypothesis was modified to accommodate complex vertical structure of forest ecosystems 
润气候区，年均降水约 $1960 \mathrm{~mm}$, 年均气温 $15.3^{\circ} \mathrm{C}$. 保护区地形较为复杂, 不同海拔分布的土壤类型有 一定差异, 主要有红壤、黄红壤、红黄壤和沼泽土 ${ }^{[19]}$. 以甜槠 (Castanopsiseyrei)、木荷 (Schima superba) 为优 势种的常绿阔叶林是保护区内常见的植被类型，广 泛分布在海拔350 800 m的区域 ${ }^{[19]}$.

2004年, 根据CTFS-ForestGEO (The Center for Tropical Forest Science-Forest Global Earth Observatory)样地建设标准, 在保护区的核心区内选择了一 片保存完好的典型常绿阔叶林建立了面积为 $24 \mathrm{hm}^{2}$ 的森林动态监测样地. 样地用全站仪划分成600个 $20 \mathrm{~m} \times 20 \mathrm{~m}$ 的样方, 并对胸径 $\geq 1 \mathrm{~cm}$ 的所有木本植物 进行调查, 鉴定到种, 挂牌、记录空间位置, 测量胸 径大小. 2005 年的调查共发现样地内有木本植物 159 种 ${ }^{[20,21]}$.

(ii) 数据变量. 本研究在 $20 \mathrm{~m} \times 20 \mathrm{~m}$ 的样方尺 度上开展, 使用的数据包括环境, 地上生物量和物种 多样性数据. 环境变量包括地形和土壤两类因子. 根 据每个样方顶点的海拔测量数据, 按 CTFS-ForestGEO的统一标准计算了各样方的凹凸度、坡度、坡向 以及平均海拔 4 个地形变量, 计算的方法详见 Legendre等人 ${ }^{[21]}$. 土壤数据来自古田山样地 2007 年 调查的基础土壤数据 ${ }^{[22]}$, 该数据包括总碳 (TC)、总氮 $(\mathrm{TN})$ 、总磷 $(\mathrm{TP})$ 、有效态的氮 $(\mathrm{N})$ 、磷 $(\mathrm{P})$ 、铝 $(\mathrm{Al})$ 、嶰 $(B)$ 、钙 $(\mathrm{Ca})$ 、铜 $(\mathrm{Cu})$ 、铁 $(\mathrm{Fe})$ 、钾 $(\mathrm{K})$ 、镁 $(\mathrm{Mg})$ 、锰 $(\mathrm{Mn})$ 、 钠 $(\mathrm{Na})$ 、硅 $(\mathrm{Si})$ 、锌 $(\mathrm{Zn})$ 、硝态氮 $\left(\mathrm{NO}_{3}{ }^{-}\right)$、铵态氮 $\left(\mathrm{NH}_{4}{ }^{+}\right)$、 氮矿化速率、土壤 $\mathrm{pH}$ 、土壤湿度、土壤容重以及根据 各元素含量计算的 TN:TP, TC:TN, TC:TP, N:P, $\mathrm{NO}^{-}: \mathrm{NH}^{+}, \mathrm{Ca}: \mathrm{K}, \mathrm{Ca}: \mathrm{Mg}, \mathrm{Mg}: \mathrm{K}, \mathrm{Mg}: \mathrm{Mn}$, 共计 31 个变量. 关于土壤的采样及具体测试分析方法详见 文献[22].

地上生物量用异速生长方程进行估算, 具体估 算方法详见Lin等人 ${ }^{[23]}$ 的研究. 物种多样性使用物种 丰富度和baker-parker优势度指数两个指标. 物种丰 富度即相应样方的物种数量, baker-parker优势度指 数为样方中胸径截面积最大物种的胸径截面积与整 个样方总胸径截面积的比值 ${ }^{[24]}$. 林冠层和林下层功 能群的划分根据物种在成年阶段树高能否超过 $15 \mathrm{~m}$ (一部分物种树高数据来源于样地内的树高实测数 据 ${ }^{[23]}$, 一部分来自植物志的记载). 成年树高能超过 $15 \mathrm{~m}$ 的物种归人林冠层, 其余的树种归人林下层. 每 个样方林冠层和林下层功能群相应的地上生物量和
物种多样指数根据各层相应的物种进行计算.

(iii) 统计分析. 一部分处于高海拔区域的样方 树木个体密度很高，可能与过去该区域受到局部雷 击火的干扰有关 ${ }^{[20]}$, 为了尽可能使本研究中的所有 样方拥有相同的干扰背景及所有样方都处于成熟林 的阶段, 分析中仅使用低海拔部分的样地 (300 mx $600 \mathrm{~m})$, 共计 450 个 $20 \mathrm{~m} \times 20 \mathrm{~m}$ 样方. 本研究获得的地 形加土壤变量共有 35 个, 对这些环境变量进行了主 成分分析，挑选出前 5 个主成分 (前5个主成分能够解 释总方差的比例分别为 $\mathrm{PC} 1=33.6 \%, \mathrm{PC} 2=15.2 \%$, $\mathrm{PC} 3=9.7 \%$, PC4 $=9.1 \%, \mathrm{PC} 5=4.5 \%$ ，总计 $72.1 \%$; 表 S1)用于后续的分析. 对地上生物量数据和物种多样 性数据进行了正态性检验, 对林下层地上生物量和 物种优势度数据进行了平方根转化来提高数据分布 的正态性.

本研究使用结构方程模型来检验环境，物种多 样性和地上生物量间的关系是否与多变量生产力-多 样性假说的预测一致. 首先, 根据概念模型(图1(c)), 拟合各变量间的关系，使用最大似然法进行参数估 计, 通过逐步简化(将所有 $P>0.01$ 路径从模型中去除) 得到最简约模型 ${ }^{[25]}$. 模型与数据的适配度用 3 个指标 来表示: 卡方值 $\left(\chi^{2}\right)$, 适配度指数 (goodness-of-fit index, $\mathrm{CFI}$ )和渐进残差均方和平方根 (root square mean error of approximation, RMSEA). $\chi^{2}$ 值不显著 $(P>0.05)$, CFI $>0.9$, RMSEA $<0.05$ 均表示模型和数据的适配度 很好 ${ }^{[25]}$. 使用标准化路径系数来比较各变量的相对 重要性 ${ }^{[25]}$. 结构方程模型运算在Amos 20.0 软件中 进行 ${ }^{[25]}$.

\section{2 结果}

基于 450 个 $20 \mathrm{~m} \times 20 \mathrm{~m}$ 样方的计算结果表明, 林 冠层地上生物量为 $(211.7 \pm 3.5) \mathrm{Mg} \mathrm{hm}^{-2}$, 是整个森林 地上生物量的主要贡献者, 而林下层的地上生物量 约为林冠层的 $1 / 10\left((20.0 \pm 0.5) \mathrm{Mg} \mathrm{hm}^{-2}\right.$; 表1). 多样 性指数方面, 林冠层的物种丰富度 $(15.4 \pm 0.2)<$ 林下 层的物种丰富度 $(20.1 \pm 0.2)$, 但林冠层的优势度 $(0.45 \pm 0.01)>$ 林下层的优势度 $((0.34 \pm 0.01)$; 表 1$)$.

结构方程模型的分析结果表明, 模型与数据间 的匹配非常好 $\left(\chi^{2}=23.84, d_{f}=24, P=0.47 ; \mathrm{GFI}=0.989\right.$; RMSEA $<0.001)$. 最终的模型分别解释了林冠层和林 下层地上生物量变异的 $30 \%$ 和 $58 \%$ (图2). 林冠层地 上生物量最重要的影响因素是林冠层优势度(标准路 
表 $120 \mathrm{~m} \times 20 \mathrm{~m}$ 样方尺度地上生物量, 优势度和物种丰富度的均值 $(\bar{x} \pm \mathrm{SE})$ 及变化范围 $(n=450)$

Table $1 \bar{x} \pm \mathrm{SE}$ and range of aboveground biomass, dominance and species richness at $20 \mathrm{~m} \times 20 \mathrm{~m}$ scale $(n=450)$

\begin{tabular}{|c|c|c|c|c|}
\hline & \multicolumn{2}{|c|}{ 林冠层 } & \multicolumn{2}{|c|}{ 林下层 } \\
\hline & $\bar{x} \pm \mathrm{SE}$ & 范围 & $\bar{x} \pm \mathrm{SE}$ & 范围 \\
\hline 地上生物量 $\left(\mathrm{Mg} \mathrm{hm}^{-2}\right)$ & $211.7 \pm 3.5$ & $55.4 \sim 482.0$ & $20.0 \pm 0.5$ & $2.1 \sim 72.1$ \\
\hline 物种丰富度 & $15.4 \pm 0.2$ & $7 \sim 25$ & $20.1 \pm 0.2$ & $11 \sim 32$ \\
\hline 优势度 & $0.45 \pm 0.01$ & $0.16 \sim 0.82$ & $0.34 \pm 0.01$ & $0.14 \sim 0.79$ \\
\hline
\end{tabular}

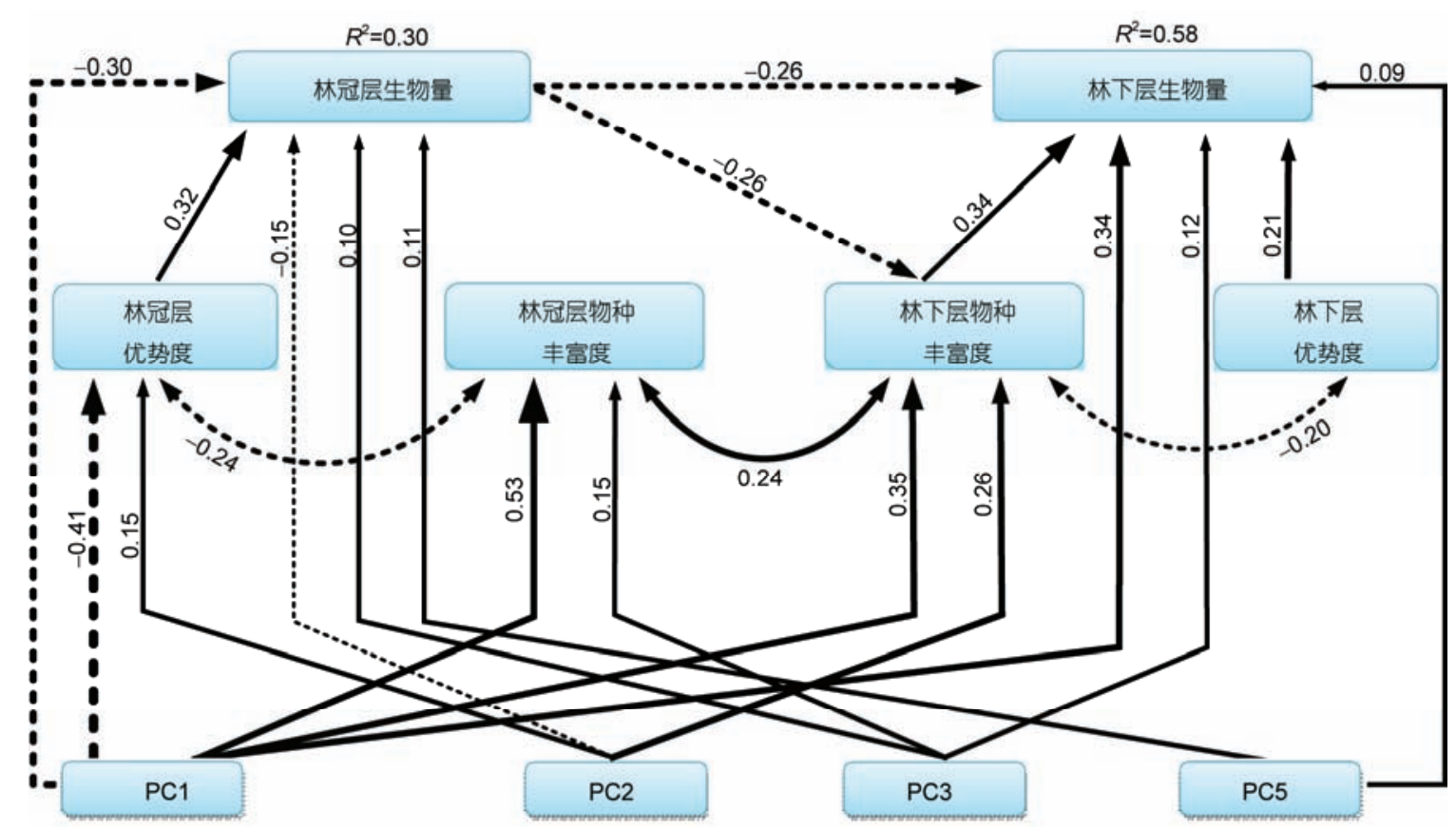

图 2 (网络版彩色)结构方程模型拟合的最优结果. 单箭头实线和虚线分别代表正的和负的直接影响, 双箭头实线和虚线条分别代表两者间正 的和负的相关关系, 线条边的数字为标准化的路径系数, 线条的粗细与路径系数成比例变化. $R^{2}$ 代表决定系数, 即被解释的变异量, 模型与数 据间匹配良好 $\left(\chi^{2}=23.84, d_{f}=24, P=0.47 ; \mathrm{GFI}=0.989 ; \mathrm{RMSEA}<0.001\right)$, 所有路径间的关系都极显著 $(P<0.001), \mathrm{PC} 1 \sim \mathrm{PC} 5$ 分别代表环境因子(主成 分分析结果)

Figure 2 (Color online) Result of structural equation modeling analysis. Continuous and dashed single-headed arrows indicate positive and negative direct effects, respectively. Continuous and dashed two-headed arrows represent positive and negative correlations between variables, respectively. The values along the arrows represent standardized path coefficients. The line thickness of the arrows is proportional to the magnitude of each path coefficient. $R^{2}$ is coefficient of determination, indicating the proportion of variation of each variable explained by the model. The final model fit well $\left(\chi^{2}=23.84, d_{f}=24, P=0.47\right.$; GFI $=0.989$; RMSEA $\left.<0.001\right)$. All of the standardized path coefficients were statistically significant at $P<0.001$ level. $\mathrm{PC} 1-\mathrm{PC} 5$ represent the environmental variables after principal component analysis

径系数为 0.32 ), 而林下层地上生物量最重要的影响 因素是林下层物种丰富度和环境因子 PC1 (标准路径 系数均为 0.34 ). 环境因子对林冠层和林下层的地上 生物量均有显著的直接影响, 同时环境因子通过影 响林冠层的优势度和林下层的物种丰富度, 从而间 接地影响各林层的地上生物量(图2和3). 此外, 环境 因子还通过影响林冠层地上生物量大小, 从而对林 下层的地上生物量产生间接影响(图3(b)).

物种多样性对各层的地上生物量有直接影响, 但在不同林层存在差异(图2). 在林冠层, 仅优势度
对地上生物量有直接影响, 而物种丰富度对地上生 物量无直接影响 (图2); 但在林下层, 物种丰富度和 优势度均对地上生物量有直接影响, 而且物种丰富 度的直接影响大于优势度的直接影响(标准路径系数 分别为 0.34 和 0.21 , 图 2 ).

林冠层生物量对林下层生物量和物种丰富度均 有负的直接影响 (标准路径系数均为 -0.26 , 图 2), 但 没有对林下层优势度产生直接影响, 同时林冠层还 通过影响林下层的物种丰富度, 从而间接地影响到 林下层的地上生物量(图3(b)). 
(a)

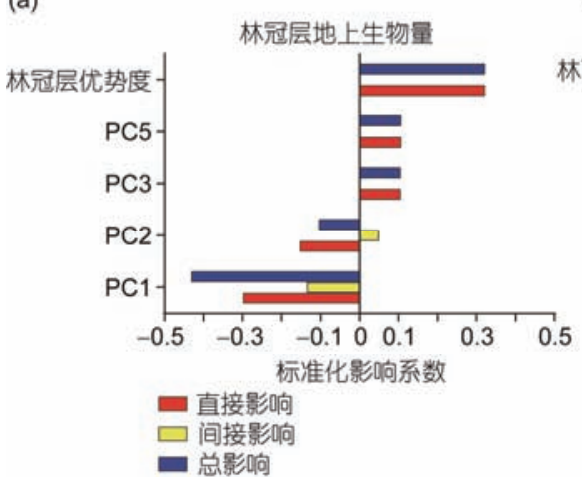

(b)

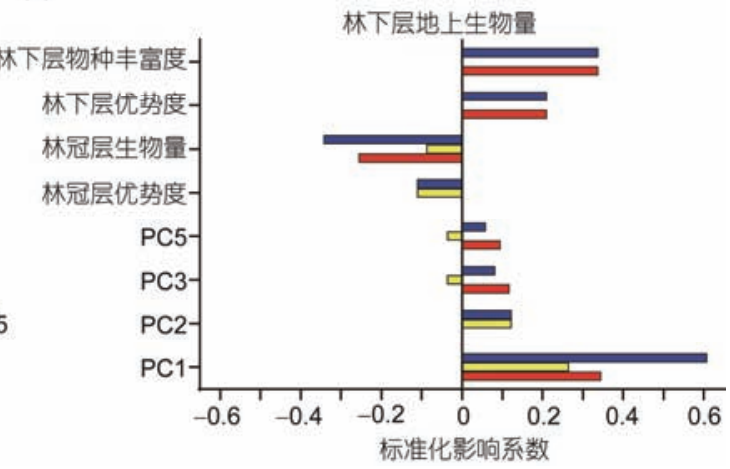

图 3 (网络版彩色) 结构方程模型中各变量对林冠层(a)和林下层(b)地上生物量的标准化影响系数. PC1 PC5 分别代表环境因子(主成分分析 结果)

Figure 3 (Color online) Standardized direct effects, indirect effects and total effects (direct plus indirect effects) derived from the structural equation model fitted to the overstorey (a) and understorey (b) aboveground biomass. PC1-PC5 represent the environmental variables after principal component analysis

\section{3 讨论}

物种多样性与生产力的关系是生态学研究中最 具争议的问题之一 ${ }^{[26]}$. 生产力如何影响物种多样性 受到很多研究的关注, 虽然目前已有丰富的理论来 解释生产力驱动物种多样性的变化 ${ }^{[8]}$, 但是这个格局 是否普遍存在还有很大的争议 ${ }^{[1,2]}$. 而随着物种丧失 等问题的突出, 生态学家从另一个角度思考两者间 的关系, 即随着物种多样性的减少生产力会发生什 么变化? 控制实验表明, 随着物种多样性的降低, 生 产力或生物量下降 ${ }^{[27]}$. 然而, 野外调查研究的结果 和控制实验结果常存在差异, 因此不能将控制实验 结论直接推广到现实复杂的生物群落中 ${ }^{[10]}$. 无论是 研究生产力对物种多样性的影响还是生产力响应物 种多样性的变化其本质关注的是两个相同的变量, 但不同的研究角度用了不同的理论来解释两者间的 关系. 整合已有理论到同一框架下是合理解释两者 关系的可行途径. 多变量生产力-多样性假说的提出 为在同一个模型中合理地解释两者间的驱动关系提 供了新思路 ${ }^{[4,5]}$. 本研究利用森林调查数据, 对改进 的多变量生产力-多样性假说进行检验(图1(c)), 分析 结果支持该假说的预测(图2).

与预测一致, 林冠层和林下层地上生物量都直 接受环境因子的影响(图2和3). 过去已有研究表明, 土壤养分、地形等因子会直接影响地上生物量的空间 分布 ${ }^{[28,29]}$. 基于多变量的分析方法, 本研究还发现, 环境因子通过间接的影响物种多样性, 从而对地上 生物量产生影响(图2和3): 在林冠层环境因子通过直 接影响优势度对地上生物量产生间接影响(图3(a)), 而在林下层则通过影响物种丰富度, 从而对地上生 物量产生间接影响(图3(b)), 这说明环境因子对林冠 层和林下层的影响机制存在一定的差异, 这可能是 因为在相同的土壤和地形条件下林冠层和林下层内 物种间的相互作用方式不同. 林冠层和林下层优势 度对地上生物量都有正的直接影响(图2和3), 这说明 不管在哪个林层, 其优势种对生物量的维持都是必 要的. 近些年基于植物功能多样性水平开展的研究 也表明, 群落的生物量或生产力很大程度上由群落 的优势物种决定 ${ }^{[16,17,30]}$. 因此, 为维持高的群落生产 力或生物量, 保护群落优势物种是必要的.

林下层物种丰富度对林下层的地上生物量有正 的直接影响(图 2和 3(b)). 至少有两个机制可以解释 物种丰富度对地上生物量的正影响关系, 包括物种 间的生态位互补(物种间的竞争作用减弱)，物种间的 互助 (一些树木的生长改变了周边环境, 促进了其他 树木的生长), 这些机制都可以促进群落对资源的利 用, 从而提高群落的生产力或生物量 ${ }^{[9]}$. 不过在林冠 层没有发现物种丰富度对地上生物量的直接影响(图 2). 这个结果不支持已有研究提出的物种丰富度和 生物量的正相关关系在森林不同林层普遍存在的结 论 $^{[15]}$. 这可能与生物多样性和生态系统功能的关系 存在背景依赖有关，即在不同环境条件下两者相关 性的强度和方向会发生改变 ${ }^{[31]}$. 胁迫梯度假说认为, 在优越的环境下物种之间更多为竞争关系, 而在不 利环境下物种间更多为互助关系, 因此在环境条件 不利的情况下发现物种丰富度和地上生物量正相互 
作用的可能性更大 ${ }^{[32]}$. 本研究中, 林冠层的光照资 源丰富, 竞争能力强的物种贡献了大量的生物量并 排斥其他物种的生存, 这导致林冠层的物种丰富度 与生物量间无显著的正关系, 而林下层的光照条件 受到林冠层的限制, 物种间的竞争减小, 更可能表现 出互助的关系. 与本文的结果不同, 对加拿大北方林 开展的研究中发现, 物种丰富度和地上生物量的正 相关关系在各林层都出现 ${ }^{[15]}$. 这可能与其研究区域 为寒温带而本文的研究区处于亚热带有关. 相比于 加拿大的北方林, 亚热带常绿阔叶林拥有更优越的 生长环境, 更大的生物量和更丰富的物种, 林冠层物 种间的竞争将可能更为激烈. Paquette和Messier ${ }^{[33]}$ 的 研究支持这个推测, 他们发现高纬度的北方针叶林 中物种间的互补作用强度要大于位于低纬度的温带 森林, 主要是因为相比于北方针叶林, 温带森林所处 的水热环境更为优越. 另外, 物种丰富度指数对生物 系统功能变异的解释度本身就比较低也可能是在林 冠层没有发现它对地上生物量有直接影响的原因.

林冠层物种的生长可能会增加林下环境的异质 性或为林下物种提供庇护环境, 从而促进林下物种 的增多, 提高林下的生产力或生物量, 但林冠层的生 长也可能过滤和占据大量的资源, 从而抑制林下物
种的生长 ${ }^{[34-36]}$. 本研究结果更符合后一种情况, 发 现林冠层地上生物量对林下层的物种丰富度和地上 生物量都存在负的直接影响(图2和3(b)). 这个结果 与Zhang等人 ${ }^{[15]}$ 对加拿大国家森林清查数据的分析 结果一致. 与此类似, 对美国北部北方林的研究也发 现, 随着样地胸径截面积的上升, 林下层物种丰富度 和植物的盖度都下降 ${ }^{[34]}$. 林冠层的生长拦截了大量 的阳光, 从而导致林下层缺乏充足的光照资源是出 现该格局的可能原因 ${ }^{[34]}$. 此外，林冠层地上生物量 还通过直接影响林下的物种丰富度, 从而间接地对 林下层生物量产生负的影响(图3(b)), 这说明林冠层 的生长也导致林下层对环境资源的利用效率下降.

\section{4 结论}

对古田山24公顷样地调查数据的分析表明, 环 境因子直接影响地上生物量的大小, 同时环境因子 通过影响群落的物种优势度和丰富度格局, 从而间 接地影响群落的地上生物量大小, 在不同的林层, 物 种多样性对地上生物量的影响格局存在差异. 该结 果符合多变量生产力-多样性假说的预测, 同时本研 究结果表明, 优势物种及高的物种丰富度对维持天 然林的生物量都是必要的. 教授、中国科学院植物研究所生物多样性与生物安全研究组的老师和学生、古田山保护区工作人员、古田山周 边民工在样地建设及野外数据调查过程中都付出了辛苦劳动, 在此一并致谢.

\section{参考文献}

1 Fraser L H, Pither J, Jentsch A, et al. Worldwide evidence of a unimodal relationship between productivity and plant species richness. Science, 2015, 349: 302-305

2 Adler P B, Seabloom E W, Borer E T, et al. Productivity is a poor predictor of plant species richness. Science, 2011, 333: 1750-1753

3 Hector A, Schmid B, Beierkuhnlein C, et al. Plant diversity and productivity experiments in European grasslands. Science, 1999, 286: $1123-1127$

4 Gross K, Cardinale B J. Does species richness drive community production or vice versa? Reconciling historical and contemporary paradigms in competitive communities. Am Nat, 2007, 170: 207-220

5 Cardinale B J, Bennett D M, Nelson C E, et al. Does productivity drive diversity or vice versa? A test of the multivariate productivitydiversity hypothesis in streams. Ecology, 2009, 90: 1227-1241

6 Loreau M, Naeem S, Inchausti P, et al. Biodiversity and ecosystem functioning: Current knowledge and future challenges. Science, 2001, 294: 804-808

7 Schmid B. The species richness-productivity controversy. Trends Ecol Evolut, 2002, 17: 113-114

8 Gillman L N, Wright S D. The influence of productivity on the species richness of plants: A critical assessment. Ecology, 2006, 87: 1234-1243

9 Hooper D U, Chapin F S, Ewel J J, et al. Effects of biodiversity on ecosystem functioning: A consensus of current knowledge. Ecol Monogr, 2005, 75: 3-35

10 Jiang L, Wan S Q, Li L H. Species diversity and productivity: Why do results of diversity-manipulation experiments differ from natural 
patterns? J Ecol, 2009, 97: 603-608

11 Cardinale B J, Hillebrand H, Harpole W S, et al. Separating the influence of resource 'availability' from resource 'imbalance' on productivity-diversity relationships. Ecol Lett, 2009, 12: 475-487

12 Borer E T, Seabloom E W, Tilman D. Plant diversity controls arthropod biomass and temporal stability. Ecol Lett, 2012, 15: 1457-1464

13 Lewandowska A M, Biermann A, Borer E T, et al. The influence of balanced and imbalanced resource supply on biodiversity-functioning relationship across ecosystems. Philos Trans R Soc Lond B Biol Sci, 2016, 371: 1694

14 Nilsson M C, Ward D A. Understory vegetation as a forest ecosystem driver: Evidence from the northern Swedish boreal forest. Front Ecol Environ, 2005, 3: 421-428

15 Zhang Y, Chen H Y H, Taylor A R, et al. Positive species diversity and above-ground biomass relationships are ubiquitous across forest strata despite interference from overstorey trees. Funct Ecol, 2017, 31: 419-426

16 Finegan B, Peña-Claros M, de Oliveira A, et al. Does functional trait diversity predict above-ground biomass and productivity of tropical forests? Testing three alternative hypotheses. J Ecol, 2015, 103: 191-201

17 Cavanaugh K C, Gosnell J S, Davis S L, et al. Carbon storage in tropical forests correlates with taxonomic diversity and functional dominance on a global scale. Glob Ecol Biogeogr, 2014, 23: 563-573

18 Chisholm R A, Muller-Landau H C, Abdul Rahman K, et al. Scale-dependent relationships between tree species richness and ecosystem function in forests. J Ecol, 2013, 101: 1214-1224

19 Yu M J, Hu Z H, Yu J P, et al. Forest vegetation types in Gutianshan National Natural Reserve in Zhejiang (in Chinese). J Zhejiang Univ (Agric Life Sci), 2001, 27: 375-380 [于明坚，胡正华，余建平，等. 浙江古田山自然保护区森林植被类型. 浙江大学学报(农业与生 命科学版), 2001, 27: 375-380]

20 Zhu Y, Zhao G F, Zhang L W, et al. Community composition and structure of Gutianshan forest dynamic plot in a mid-subtropical evengreen broad-leaved forest, east China (in Chinese). Chin J Plant Ecol, 2008, 32: 262-273 [祝燕, 赵谷风，张俪文，等. 古田山中亚 热带常绿阔叶林动态监测样地——群落组成与结构. 植物生态学报, 2008, 32: 262-273]

21 Legendre P, Mi X C, Ren H B, et al. Partitioning beta diversity in a subtropical broad-leaved forest of China. Ecology, 2009, 90: $663-674$

22 Zhang L W. The effect of spatial heterogeneity of environmental factors on species distribution and community structure (in Chinese). Doctor Dissertation. Beijing: Graduate School of Chinese Academy of Sciences, 2010 [张俪文. 环境空间异质性对物种空间分布和群 落结构的影响. 博士学位论文. 北京: 中国科学院研究生院, 2010]

23 Lin D, Lai J, Muller-Landau H C, et al. Topographic variation in aboveground biomass in a subtropical evergreen broad-leaved forest in China. PLoS One, 2012, 7: e48244

24 Berger W H, Parker F L. Diversity of planktonic foraminifera in deep-sea sediments. Science, 1970, 168: 1345-1347

25 Arbuckle J L. IBM SPSS Amos 20 User's Guide. New York: IBM Corp., 2011

26 Willig M R. Biodiversity and productivity. Science, 2011, 333: 1709-1710

27 Cardinale B J, Duffy J E, Gonzalez A, et al. Biodiversity loss and its impact on humanity. Nature, 2012, 486: 59-67

28 Paoli G D, Curran L M, Slik J W F. Soil nutrients affect spatial patterns of aboveground biomass and emergent tree density in southwestern Borneo. Oecologia, 2008, 155: 287-299

29 Ferry B, Morneau F O, Bontemps J D, et al. Higher treefall rates on slopes and waterlogged soils result in lower stand biomass and productivity in a tropical rain forest. J Ecol, 2010, 98: 106-116

30 Conti G, Diaz S. Plant functional diversity and carbon storage-an empirical test in semi-arid forest ecosystems. J Ecol, 2013, 101: $18-28$

31 Cardinale B J, Nelson K, Palmer M A. Linking species diversity to the functioning of ecosystems: On the importance of environmental context. Oikos, 2000, 91: 175-183

32 Maestre F T, Callaway R M, Valladares F, et al. Refining the stress-gradient hypothesis for competition and facilitation in plant communities. J Ecol, 2009, 97: 199-205

33 Paquette A, Messier C. The effect of biodiversity on tree productivity: From temperate to boreal forests. Glob Ecol Biogeogr, 2011, 20: $170-180$

34 Reich P B, Frelich L E, Voldseth R A, et al. Understorey diversity in southern boreal forests is regulated by productivity and its indirect impacts on resource availability and heterogeneity. J Ecol, 2012, 100: 539-545

35 Holmgren M, Lin C Y, Murillo J E, et al. Positive shrub-tree interactions facilitate woody encroachment in boreal peatlands. J Ecol, 2015, 103: 58-66

36 Bartels S F, Chen H Y H. Is understory plant species diversity driven by resource quantity or resource heterogeneity? Ecology, 2010, 91: $1931-1938$ 


\title{
Multivariate relationship between tree diversity and aboveground biomass across tree strata in a subtropical evergreen broad-leaved forest
}

\author{
LIN DunMei ${ }^{1 *}$, PANG Mei $^{1}$, LAI JiangShan ${ }^{2}$, MI XiangCheng ${ }^{2}$, REN HaiBao $^{2} \&$ MA KePing ${ }^{2}$ \\ ${ }^{1}$ Key Laboratory of the Three Gorges Reservoir Region's Eco-Environment, Ministry of Education, Chongqing University, Chongqing 400045, China; \\ ${ }^{2}$ State Key Laboratory of Vegetation and Environmental Change, Institute of Botany, Chinese Academy of Sciences, Beijing 100093, China \\ *Corresponding author, E-mail: lindunmei@cqu.edu.cn
}

The correlation between primary producer diversity and the productivity (or biomass) of ecosystems is one of the most important and broadly studied relationship in ecology. Ecologists have discussed this relationship from two fundamentally different perspectives. Historically, productivity has been viewed as driver of species diversity. Recently, many studies have demonstrated that diversity can also control, rather than responds to, the production of biomass. These contrasting points of view have led to the debate about whether species diversity is the cause or the consequence of community productivity. Multivariate productivity-diversity hypothesis has been put forward to reconciling this debate. This hypothesis state that: (i) the environmental factors are the direct driver of species that can coexist within an area; (ii) the biomass of the area is directly influenced by the environmental factors that limit production; (iii) the environmental factors indirectly influenced biomass of the area via influencing the species number to coexist within the area that affects how efficiently environmental resources are converted into biomass. To date, empirical support for this hypothesis is scarce, especially for structurally complex terrestrial ecosystems. In this study, we modified multivariate productivitydiversity hypothesis to accommodate complex vertical structure of forest ecosystems, and used structural equation modeling and data from a large evergreen broad-leaved forest dynamic plot $\left(24 \mathrm{hm}^{2}\right.$ in area) in subtropical China to understand the causal relationships among environmental factors, species richness, dominance and aboveground biomass. Trees were grouped into tow functional groups (overstorey and understorey) in order to improve the ability to detecting the diversity effect. The final model explained $30 \%$ and $58 \%$ of the variation in aboveground biomass of overstorey and understorey, respectively. Dominance was the most important factor in explaining the variation of aboveground biomass of overstorey, while both species richness and environment factors were the most important factors in explaining the variation of aboveground biomass of understorey. Consistent with the predictions of multivariate productivity-diversity hypothesis, (i) aboveground biomass were directly influenced by the environmental factors in both overstorey and understorey; (ii) environmental factors directly influence tree dominance and species richness of overstorey, but only directly influence species richness of understorey; (iii) environmental factors indirectly influence aboveground biomass of overstorey by influencing dominant, while indirectly influence aboveground biomass of understorey by influencing species richness. Interestingly, species richness was only important to explaining variation in aboveground biomass of understorey. This may be attributed to the low light condition in understorey, which may alleviative competition among trees of understorey. To our knowledge, this study provides the first empirical evidence supporting the multivariate productivity-diversity hypothesis in forest ecosystem thus contributes to extending the generality of this framework. Our result also highlights both dominant species and higher species richness is required to maximizing forest biomass.

biodiversity and productivity, biomass, overstorey-understorey interaction, competitive exclusion, structural equation modeling

doi: $10.1360 /$ N972016-01072 